Short Communication

\title{
Herbicides have negligible effects on ants and springtails in an Australian wheat field
}

\author{
Penelope J.M. Greenslade ${ }^{\mathrm{a}, \mathrm{c}, *}$, Ian A. Reid ${ }^{\mathrm{a}}$, Ian J. Packer ${ }^{\mathrm{b}}$ \\ ${ }^{a}$ Formerly of CSIRO Division of Entomology, GPO Box 1700, ACT 2601, Australia \\ ${ }^{\mathrm{b}}$ Formerly of Department of Conservation and Land Management Research Centre, Cowra, NSW 2794, Australia \\ ${ }^{\mathrm{c}}$ Environmental Management, University of Ballarat, Mt Helen Campus, Ballarat, Victoria 3350, Australia
}

\section{A R T I C L E I N F O}

Article history:

Received 8 December 2009

Received in revised form 14 March 2010

Accepted 16 March 2010

Available online $\mathrm{xxx}$

\section{Keywords:}

Conservation farming

Conventional tillage

Bromoxynil

Hoegrass

Jeannenotia stachi

Hemisotoma thermophila

Brachystomella platensis

Collembola

Formicidae

\begin{abstract}
A B S T R A C T
The effects of herbicides applied to a direct drilled and traditionally tilled wheat field on trap catches of the abundant Collembola and Formicidae were examined. Significantly higher abundances of Collembola and species richness of ants were found on the direct-drilled plots. A significant effect of the herbicides, bromoxynil $\left(\mathrm{C}_{7} \mathrm{H}_{3} \mathrm{Br}_{2} \mathrm{NO}\right)$ and hoegrass (diclofop-methyl), on the activity of two of the fourteen species of surface-dwelling Collembola was detected but no effect was observed on surface-active Formicidae. Jeannenotia stachi numbers were significantly more reduced on the direct-drilled compared to the traditionally tilled plot after herbicide treatment possibly because of higher predator abundance on the latter. In the short term, herbicides have a minimal effect on most species of surface-active arthropods although Collembola were more adversely affected than Formicidae.
\end{abstract}

(c) 2010 Elsevier Ltd. All rights reserved.
Australian cropping practices have traditionally involved cultivation and long periods of fallow resulting in soil degradation. Conservation farming such as direct drilling leaves soils less susceptible to degradation. Using minimum cultivation requires herbicides to control weeds. Soil organisms are important in notillage farming regimes because of their contribution to soil fertility and nutrient cycling (Longstaff et al., 1997) but herbicides can adversely affect these beneficials (Eijsackers and van de Bund, 1980).

Field data on the effects of herbicides on soil fauna in the Northern Hemisphere have indicated that herbicides have little effect in the short term on the activity and abundance of soil fauna (Eijsackers and van de Bund, 1980; Kulshrestha and Singh, 1994). However, laboratory studies show that some species are adversely affected by contact with these chemicals (Mola et al., 1987; Sabatini et al., 1998). Herbicide application has been reported to alter rates

\footnotetext{
* Corresponding author. Environmental Management, University of Ballarat, Mt Helen Campus, Ballarat, Victoria 3350, Australia.

E-mail address: Pgreenslade@staff.ballarat.edu.au (P.J.M. Greenslade).
}

of organic matter decomposition and lead to nutrient loss in the long term (Hendrix and Parmelee, 1985) but short term effects on these processes may differ. Overseas literature on this topic is extensive (Eijsackers and van de Drift, 1976), but there is apparently no extant published data relating to Australia.

We investigated the short-term effect of two herbicides, commonly used by wheat farmers in central New South Wales, on surface-active arthropod fauna of broad-acre arable land in southeastern Australia. Collembola are appropriate for study because of their sensitivity to chemical impacts, high activity and abundance, ubiquity and are considered functionally important in soils (Eijsackers and van de Bund, 1980; Greenslade and Greenslade, 1983). Laboratory studies have shown some species of Collembola are susceptible to herbicides via direct effects on activity, reproduction, and development (Eijsackers, 1978a, 1978b; Fratello et al., 1986; Badejo and van Straalen, 1992). As surfaceactive Collembola are most likely to come in contact with chemical sprays, we used pitfall trapping for sampling and ants (Formicidae) were also recorded as dominant predators.

A tillage trial planted with winter wheat and established since 1980 at the New South Wales Department of Conservation and 
Table 1

Numbers of individuals of Collembola species caught in pitfall traps on each treatment subplot and on each sampling occasion expressed as means per trap per 5 days.

\begin{tabular}{|c|c|c|c|c|c|c|c|c|}
\hline Tillage treatment & DD & DD & $\mathrm{DD}$ & DD & DD & DD & $\mathrm{DD}$ & DD \\
\hline Sampling period & Sample 1 & Sample 2 & Sample 1 & Sample 2 & Sample 1 & Sample 2 & Sample 1 & Sample 2 \\
\hline Treatment time & Prespray & Postspray & Prespray & Postspray & Prespray & Postspray & Prespray & Postspray \\
\hline Herbicide treatment & + herbicide & + herbicide & - herbicide & - herbicide & + herbicide & + herbicide & - herbicide & - herbicide \\
\hline Replicate & Rep 1 & Rep 1 & Rep 1 & Rep 1 & Rep 2 & Rep 2 & Rep 2 & Rep 2 \\
\hline Brachystomella platensis Najt and Massoud & 173 & 84 & 153 & 175 & 114 & 75 & 162 & 121 \\
\hline Ceratophysella gibbosa (Bagnall) & 57 & 38 & 77 & 52 & 410 & 164 & 940 & 454 \\
\hline Hemisotoma thermophila (Axelson) & 131 & 28 & 173 & 44 & 194 & 17 & 120 & 27 \\
\hline Lepidocyrtus kuakea Christiansen and Bellinger & 0 & 0 & 0 & 1 & 1 & 0 & 1 & 0 \\
\hline Drepanura spp. & 4 & 2 & 2 & 4 & 2 & 2 & 0 & 3 \\
\hline Entomobrya multifasciata (Tullberg) & 0 & 1 & 0 & 1 & 1 & 1 & 2 & 2 \\
\hline Entomobrya unostrigata Stach & 2 & 3 & 2 & 5 & 1 & 2 & 2 & 2 \\
\hline Lepidosira nigrocephala Womersley & 0 & 1 & 1 & 2 & 4 & 1 & 1 & 1 \\
\hline Indet. imm. Entomobryidae & 4 & 2 & 4 & 9 & 31 & 6 & 3 & 4 \\
\hline Jeannenotia stachi (Jeannenot) & 105 & 24 & 33 & 13 & 89 & 8 & 69 & 36 \\
\hline Katianna australis Womersley & 166 & 95 & 55 & 73 & 10 & 42 & 103 & 84 \\
\hline Sminthurinus elegans Fitch & 15 & 8 & 6 & 6 & 2 & 5 & 10 & 8 \\
\hline Sminthurinus sp. & 2 & 2 & 1 & 2 & 0 & 1 & 2 & 1 \\
\hline Indet. imm. Sminthuridae & 1 & 1 & 0 & 0 & 0 & 1 & 0 & 1 \\
\hline Tillage treatment & TT & $\mathrm{TT}$ & TT & TT & TT & TT & TT & TT \\
\hline Treatment time & Prespray & Postspray & Prespray & Postspray & Prespray & Postspray & Prespray & Postspray \\
\hline Sampling period & Sample 1 & Sample 2 & Sample 1 & Sample 2 & Sample 1 & Sample 2 & Sample 1 & Sample 2 \\
\hline Herbicide treatment & + herbicide & + herbicide & - herbicide & - herbicide & + herbicide & + herbicide & - herbicide & - herbicide \\
\hline Replicate & Rep 1 & Rep 1 & Rep 1 & Rep 1 & Rep 2 & Rep 2 & Rep 2 & Rep 2 \\
\hline B. platensis & 93 & 21 & 59 & 23 & 25 & 6 & 36 & 3 \\
\hline C. gibbosa & 191 & 79 & 63 & 62 & 33 & 6 & 51 & 39 \\
\hline H. thermophila & 212 & 43 & 195 & 43 & 60 & 33 & 136 & 56 \\
\hline Lepidocyrtus kukua & 0 & 0 & 0 & 0 & 0 & 0 & 0 & 0 \\
\hline Drepanura spp. & 0 & 0 & 0 & 0 & 0 & 0 & 0 & 0 \\
\hline Entomobrya multifasciata & 0 & 0 & 0 & 0 & 0 & 0 & 0 & 0 \\
\hline Entomobrya unostrigata & 0 & 0 & 0 & 0 & 0 & 0 & 0 & 0 \\
\hline Lepidosira nigrocephala & 0 & 0 & 0 & 0 & 0 & 0 & 0 & 0 \\
\hline Indet. imm. Entomobryidae & 6 & 4 & 7 & 11 & 2 & 2 & 5 & 2 \\
\hline J. stachi & 19 & 14 & 10 & 17 & 11 & 4 & 13 & 10 \\
\hline K. australis & 96 & 69 & 92 & 80 & 72 & 63 & 116 & 108 \\
\hline Sminthurinus elegans & 11 & 2 & 7 & 7 & 7 & 3 & 9 & 5 \\
\hline Sminthurinus sp. & 1 & 1 & 1 & 2 & 1 & 1 & 1 & 0 \\
\hline Indet. imm. Sminthuridae & 0 & 0 & 0 & 0 & 0 & 0 & 0 & 0 \\
\hline
\end{tabular}

a

B. platensis

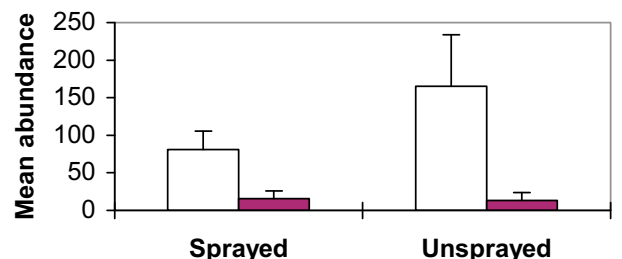

b

C. gibbosa

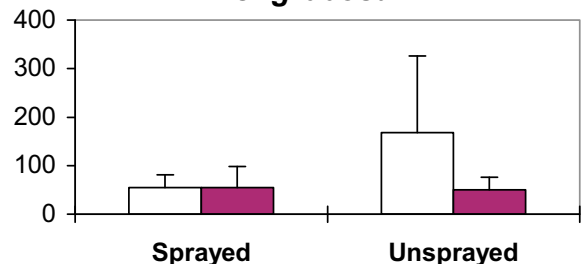

C

\section{H. thermophila}

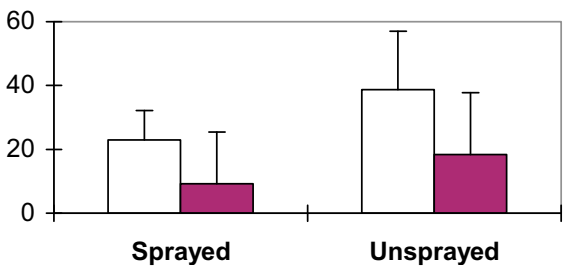

d

J. stachi

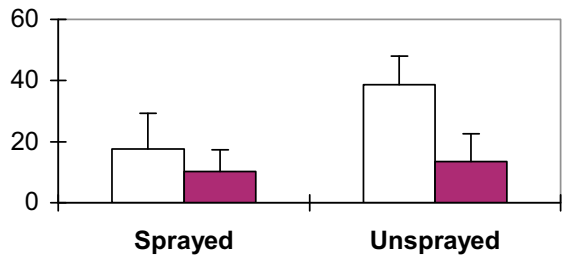

e

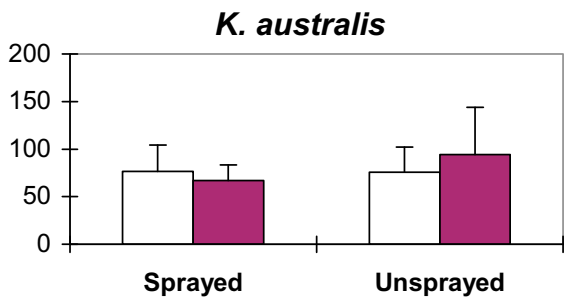

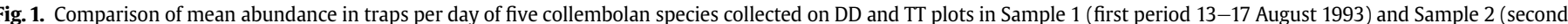
period 18-23 August 1993) combined. Paler columns represent DD plots and darker columns TT plots. Error bars denote standard deviation. 
Table 2

Results of the analysis of variance.

\begin{tabular}{|c|c|c|c|}
\hline Factor 1 & Factor 2 & F value & $P$ value \\
\hline \multicolumn{4}{|c|}{$\begin{array}{l}\text { a) Data from first sampling period, i. e. preherbicide sample, using square-root } \\
\text { transformed data. Significant probabilities to three decimal places are given } \\
\text { in bold. }\end{array}$} \\
\hline B. platensis & Tillage & 46.83 & $<0.001$ \\
\hline B. platensis & Herbicide & 1.233 & 0.688 \\
\hline C. gibbosa & Tillage & 16.730 & $<0.001$ \\
\hline C. gibbosa & Herbicide & 0.800 & 0.375 \\
\hline H. thermophila & Tillage & 0.012 & 0.912 \\
\hline H. thermophila & Herbicide & 0.087 & 0.769 \\
\hline J. stachi & Tillage & 39.954 & $<0.001$ \\
\hline J. stachi & Herbicide & 0.006 & 0.937 \\
\hline K. australis & Tillage & 0.014 & 0.906 \\
\hline K. australis & Herbicide & 0.014 & 0.906 \\
\hline \multicolumn{4}{|c|}{$\begin{array}{l}\text { b) Data from second sampling period, ie post-herbicide sample, using square- } \\
\text { root transformed data. Significant probabilities given in bold. }\end{array}$} \\
\hline B. platensis & Tillage & $<0.001$ & $<0.001$ \\
\hline B. platensis & Herbicide & 6.550 & $<0.05$ \\
\hline C. gibbosa & Tillage & 8.627 & $<0.05$ \\
\hline C. gibbosa & Herbicide & 3.743 & 0.058 \\
\hline H. thermophila & Tillage & 11.976 & $<0.001$ \\
\hline H. thermophila & Herbicide & 6.013 & $<0.05$ \\
\hline J. stachi & Tillage & 4.448 & $<0.05$ \\
\hline J. stachi & Herbicide & 2.510 & 0.118 \\
\hline K. australis & Tillage & 0.224 & 0.638 \\
\hline K. australis & Herbicide & 1.976 & 0.165 \\
\hline \multicolumn{4}{|c|}{$\begin{array}{l}\text { c) Results of ANOVA analysis for interactions between tillage, time and herbicide } \\
\text { treatment. }\end{array}$} \\
\hline B. platensis & Herbicide $\times$ date $\times$ tillage & 0.000 & 0.984 \\
\hline C. gibbosa & Herbicide $\times$ date $\times$ tillage & 0.803 & 0.372 \\
\hline H. thermophila & Herbicide $\times$ date $\times$ tillage & 0.237 & 0.627 \\
\hline J. stachi & Herbicide $\times$ date $\times$ tillage & 1.715 & 0.193 \\
\hline K. australis & Herbicide $\times$ date $\times$ tillage & 0.550 & 0.460 \\
\hline
\end{tabular}

Land Management Research Centre at Cowra, $\left(143^{\circ} 42^{\prime} \mathrm{S} 33^{\circ} 51^{\prime} \mathrm{E}\right.$, elevation $384 \mathrm{~m}$ ) was sampled. It consisted of two plots of approximately $200 \mathrm{~m} \times 45 \mathrm{~m}$ (0.9 ha) each within a larger field, running along a contour line with an $8 \%$ slope in a southeasterly direction. One plot was direct-drilled (DD) and the other traditionally tilled (TT) (Packer et al., 1992). The soil is a red duplex (Rd 3.22/Dr 3.23) with a hard setting sandy loam surface texture (Northcote, 1979) or a Xeralfic Alfisol (Soil Survey Staff, 1975). Mean annual rainfall is $645 \mathrm{~mm}$ fairly evenly distributed throughout the year. Mean daily maximum temperatures are $30.8{ }^{\circ} \mathrm{C}$ in summer and $12.8^{\circ} \mathrm{C}$ in winter with the respective minima being $16.3^{\circ} \mathrm{C}$ and $3.6^{\circ} \mathrm{C}$. Management consists of sowing from May to July after sufficient autumn rain has fallen, and harvesting is from December to January.

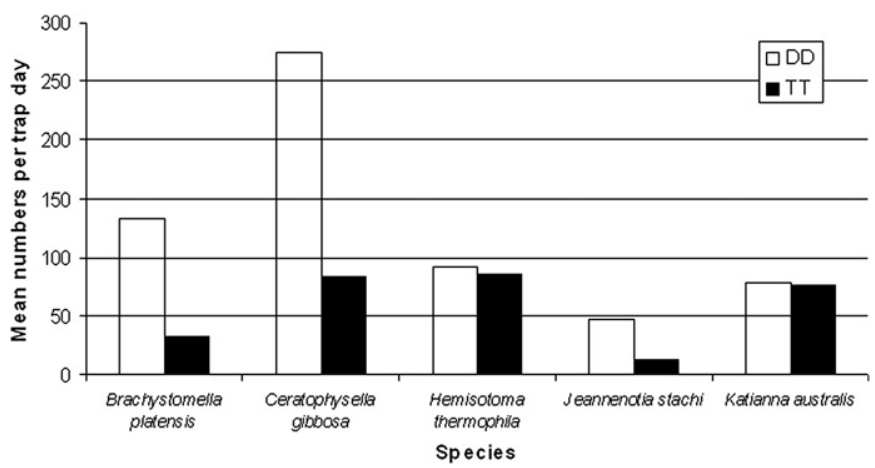

Fig. 2. Comparison of abundance of native (K. australis, B. platensis) and introduced (C. gibbosa, H. thermophila, J. stachi) Collembola in traps in both tillage treatments from Sample 1 (13-17 August 1993) as mean numbers per trap per day. Paler columns represent DD plots and darker columns TT plots.

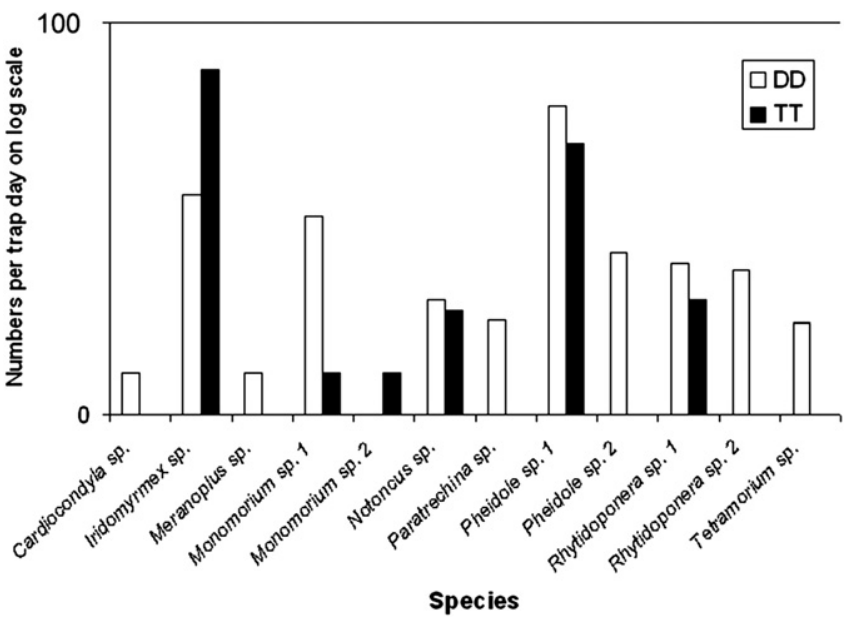

Fig. 3. Log abundance of ant morphospecies trapped in the two tillage treatments. Paler columns represent DD plots and darker columns TT plots.

A representative area (subplot) of $20 \times 20 \mathrm{~m}$ was selected in the treatment plots and divided into four $10 \times 10 \mathrm{~m}$ square block. Sampling was in late winter after moist weather when wheat was well grown being $30 \mathrm{~cm}$ high. Ten pitfall traps, $1.8 \mathrm{~cm}$ diameter, three quarters filled with 95\% ethanol (Greenslade and Greenslade, 1971), were placed randomly within each block on 13 August 1993 (Sample 1). After collection on 18 August 1993 two of the four blocks in each subplot were selected at random and sprayed with $2 \mathrm{~L}$ of Hoegrass and 1.4 L of Bromoxynil/MCPA plus surfactant, while the remaining two blocks in each field were unsprayed. New traps were placed from 19 to 24 August (Sample 2). Six mm of rain fell during Sample 1 and the average sunshine was $5.22 \mathrm{~h} \mathrm{~d}^{-1}$. No rain fell during Sample 2 and average sunshine was $9.09 \mathrm{~h} \mathrm{~d}^{-1}$. Both ants and Collembola were sorted into species or morphospecies and counted.

Analysis of variance was carried out on the Collembola using SYSTAT 6.0 for Windows and a square-root transformation. Simpson's diversity index (Southwood, 1964) was calculated for ants.

The 160 pitfall traps collected 64,536 Collembola, comprising 13 species (Table 1). Five species: Jeannenotia stachi (Jeannenot) (5\%), Katianna australis Womersley (17\%), Brachystomella platensis Najt \& Massoud (17\%), Ceratophysella gibbosa (Bagnall) (40\%)and Hemisotoma thermophila (Axelson) (18\%), represented 97\% of the Collembola trapped.

Fewer Collembola were trapped in Sample 2 than Sample 1 but both samples trapped more Collembola on DD than on TT subplots (Fig. 1). In Sample 1, significantly $(p<0.05)$ higher numbers of three species, B. platensis, C. gibbosa and J. stachi, while in Sample 2 significantly higher numbers of four species, B. platensis, C. gibbosa, $J$. stachi and $H$. thermophila were trapped in DD compared to TT subplots (Table 2a and b).

Numbers of each collembolan species in each of the eight blocks did not vary significantly from each other in pre-treatment samples. After the application of herbicide, significantly fewer individuals of $B$. platensis and $H$. thermophila were trapped on the

Table 3

Simpson's index of diversity for Formicidae genera.

\begin{tabular}{lllll}
\hline $\begin{array}{l}\text { Tillage } \\
\text { treatment }\end{array}$ & $\begin{array}{l}\text { First sample, } \\
\text { treatment plot }\end{array}$ & $\begin{array}{l}\text { Second sample, } \\
\text { treatment plot }\end{array}$ & $\begin{array}{l}\text { First sample, } \\
\text { control plot }\end{array}$ & $\begin{array}{l}\text { Second sample, } \\
\text { control plot }\end{array}$ \\
\hline DD & 1.717 & 2.188 & 1.750 & 3.036 \\
TT & 1.234 & 1.223 & 2.537 & 1.181 \\
\hline
\end{tabular}


treatment than control blocks (Table $2 \mathrm{~b}$ ). The limited replication did not enable interactions between tillage and herbicide to be tested (Table 2c). There was no difference in relative numbers of native versus introduced species between the DD and TT subplots and both groups were more abundant on the DD than the TT subplots (Fig. 2). The opposite trend was found for J. stachi which were significantly more reduced on the DD compared to the TT blocks after herbicide treatment (Fig. 1).

Twelve morphospecies of ants were distinguished in the trap catches (Fig. 3). Simpson's index of diversity showed that the DD blocks had a higher diversity than the TT blocks for three of the four treatments/samples (Table 3 ). The data were strongly influenced by catches from two traps that caught excessively high numbers of ants (Fig. 3). If these two traps were excluded from the ANOVA calculation, the abundance in traps of Pheidole spp., a seedharvesting genus, was significantly different between tillage treatments $(p<0.05)$ and total predatory ants and Rhytidoponera spp. differed between Samples 1 and $2(p<0.005, p<0.05$ respectively).

Proportions of native versus introduced species were similar on all plots. J. stachi numbers were significantly more reduced on the herbicide treated DD compared to the herbicide treated TT subplots might be the result of higher numbers of ant predators on the DD subplots (Fig. 1d). Higher numbers of ants active on the ground surface in Sample 2 compared to Sample 1 were probably because of higher temperatures.

Greater differences were found between tillage treatment and between sampling periods than between herbicide application indicating the greater influence of weather and long term management than herbicides on fauna. Three of the species examined, J. stachi, B. platensis and C. gibbosa, showed significantly higher activity in the DD than the TT subplots as shown for Collembola generally overseas (Edwards and Lofty, 1977; Wardle et al., 1993a, b). In Australia, Malinda et al. (1982) reported on soil faunal responses to hoegrass and buctil with tillage over a longer term, identified the fauna to family only, sampled the soil and were confounded by seasonal effects.

The only sensitive species, $H$. thermophila and $B$. platensis, are diurnally surface-active so were directly exposed to herbicides. The cuticle of both species has a more simplified structure than the other three species so would be less hydrophobic (P. Greenslade, unpublished observations).

A beneficial effect of DD management was in increasing predatory ant species richness on the DD plot compared to TT so exerting better control of herbivorous pests. Herbicides did not affect diversity or abundance of ants trapped probably because soil nesting colonies are protected against surface impacts.

This study is the first in Australia at species-level for effects of herbicides on surface-active Collembola and ants of tilled and direct-drilled soils on broad-acre arable land (Malinda et al., 1982; Park and Lees, 2004; Lindsay, 2004). Our results indicate that in late winter, herbicides have a minimal effect in the short term on the most surface-active fauna in wheat fields and conservation farming results in a more abundant and diverse soil fauna compared to traditionally tilled fields.

\section{Acknowledgements}

The authors are grateful to staff of the Soil Conservation Laboratory at Cowra Research Station who took the samples for us and managed the plots and to the Rural Industries Research and Development Corporation for funding the project. B. Longstaff, M. Hodda and J. Lytton-Hitchins made useful suggestions to improve the manuscript.

\section{References}

Badejo, M.A., van Straalen, N.M., 1992. Effects of atrazine on growth and reproduction of Orchesella cincta (Collembola). Pedobiologia 36, 221-230.

Edwards, C.A., Lofty, J.R., 1977. The influence of invertebrates on root growth of crops with minimal or zero cultivation. Ecological Bulletin 25, 348-356.

Eijsackers, H., 1978a. Side effects of the herbicide 2,4,5-T on reproduction food consumption and moulting of the springtail Onychiurus quadriocellatus Gisin (Collembola). Zeitschrift für Angewandte Entomologie 85 341-360.

Eijsackers, H., 1978b. Side effects of the herbicide 2,4,5-T affecting mobility and mortality of the springtail Onychiurus quadriocellatus Gisin (Collembola: Onychiuridae). Zeitschrift für Angewandte Entomologie 86, 349-372.

Eijsackers, H., Drift van de, J., 1976. Herbicides and the soil fauna. In: Audus, L.J. (Ed.) Herbicides, Physiology, Bio-chemistry, Ecology, vol. 2. Academic Press, New York, pp. 149-174.

Eijsackers, H., van de Bund, C.F., 1980. Effects on soil fauna. In: Hance, R.J. (Ed.), Interactions between Herbicides and the Soil. Academic Press, London, pp. 255-305.

Fratello, B., Bertolani, R., Sabatini, M.A., Mola, L., 1986. Effects of the herbicide atrazine on Collembola. In: Dallai, R. (Ed.), 2nd International Seminar on Apterygota. University of Siena, Siena, pp. 143-148.

Greenslade, Penelope, Greenslade, P.J.M., 1971. The use of baits and preservatives in pitfall traps. Journal of the Australian Entomological Society 10, 253-260.

Greenslade, P.J.M., Greenslade, Penelope, 1983. In: Lee, K.E. (Ed.), Ecology of Soil Invertebrates. Soils: an Australian Viewpoint. CSIRO, Melbourne, pp. 645-668.

Hendrix, P.F., Parmelee, R.W., 1985. Decomposition, nutrient loss and microarthropod densities in herbicide-treated grass litter in a Georgia piedmont agroecosystem. Soil Biology and Biochemistry 4, 421-428.

Kulshrestha, G., Singh, S.B., 1994. Effects of herbicides on soil environment. In: Prasad, D., Gaur, H.S. (Eds.), Soil Environment and Pesticides. Venus Publishing House, New Delhi, India, pp. 293-313.

Lindsay, E.A., 2004. The impact of Chrysanthemoides monilifera spp. rotunda (bitou bush) on coastal ecosystem processes. Ph D. Thesis, University of Wollongong.

Longstaff, B.C., Greenslade, PJ.M., Colloff, M., Reid, I., Hart, P., Packer, I, 1997. The Impact of Soil Tillage Practice on Soil Fauna in the NSW Wheat Belt. Research Paper No. 97. Rural Industries Research and Development Corporation, Canberra.

Malinda, D.K., Oades, J.M., Hutson, B.R., 1982. Effects of herbicides (hoegrass and buctril) on soil invertebrates in South Australian cereal crops. In: Lee, K.E. (Ed.), Proceedings of the 3rd Conference on Grassland Invertebrate Ecology Adelaide 30 Nov-4 Dec 1981. South Australian Government Printing Division, Plympton, pp. 291-298.

Mola, L., Sabatini, M.A., Fratello, B., Bertolani, R., 1987. Effects of atrazine on two species of Collembola (Onychiuridae) in laboratory tests. Pedobiologia 30, 145-149.

Northcote, K.H., 1979. A Factual Key for the Recognition of Australian Soils, fourth ed. Rellim Technical Publications, Adelaide.

Packer, I.J., Hamilton, G.J., Koen, T.B., 1992. Runoff, soil loss and soil physical property changes of light textured surface soils from long-term tillage treatments. Australian Journal of Soil Research 30, 789-806.

Park, E.K., Lees, E.M., 2004. The interaction of endosulfan with the Collembolan, Proisotoma minuta (Tullberg): toxicity, the effects of sub-lethal concentrations and metabolism. Pest Management Science 60, 710-718.

Sabatini, M.A., Rebecchi, L., Cappi, C., Guidi, A., Dinelli, G., Vicari, A., Bertolani, R., 1998. Side effects of the herbicide triasulfuron on Collembola under laboratory conditions. Chemosphere 37, 2963-2973.

Soil Survey Staff, 1975. Soil Taxonomy Handbook, 436. United States Department of Agriculture, Washington, D.C.

Southwood, T.R.E., 1964. Ecological Methods. Methuen, London.

Wardle, D.A., Yeates, G.W., Watson, R.N., Nicholson, K.S., Ahmed, M., 1993a. The below-ground food-web as an indicator of disturbances resulting from weed management practices in two contrasting agro-ecosystems. In: Popay, A.J. (Ed.), Proceedings of the 46th Plant Protection Conference 1993. The New Zealand Plant Protection Society Inc, Christchurch, pp. 338-343.

Wardle, D.A., Nicholson, K.S., Yeates, G.W., 1993b. Effect of weed management strategies on some soil-associated arthropods in maize and asparagus ecosystems. Pedobiologia 37, 257-269. 